\title{
SISTEM EKONOMI KAPITALISME
}

\section{Rizky Wahyuni}

\section{Pengertian Kapitalisme}

Kapitalisme merupakan sebuah teknik pertukaran kekayaan yang terhimpun diinvestasikan kembali oleh pemilik pribadi untuk mendapatkan keuntungan, distribusi dan produksi. Kapitalisme adalah sebuah cara atau metode yang dirancang dalam rangka untuk mendorong pengembangan profitabel melewati sekat-sekat mengarah pada skala nasional dan internasional. ${ }^{1}$

Kapitalisme merupakan sebuah sistem organisasi ekonomi yang dicirikan oleh hak milik privat atas alat-alat produksi dan distribusi yang pemanfaatannya untuk mencapai laba dalam kondisi yang sangat kompetitif. Selajutnya pengertian sistem ekonomi kapitalis adalah suatu sistem yang memberikan kebebasan yang cukup besar bagi pelaku-pelaku ekonomi untuk melakukan kegiatan yang terbaik bagi kepentingan individual atas sumberdaya-sumberdaya ekonomi atau faktor-faktor produksi. ${ }^{2}$

\section{Menurut Para Ahli :}

1. Adam Smith mendifinisikan kapitalisme sebagai sebuah sistem ekonomi bercirikan kepemilikan perorangan atas perkakas produksi, distribusi dan pendayagunaan untuk mendapatkan keungtungan dalam keadaan yang kompetitif.

2. Max Weber, mendifinisikan kapitalisme adalah sebuah cara produksi komoditi yang berlandaskan kerja berhonorarium untuk dipasarkan dan sebagai sistem produksi komoditi berdasarkan kerja berupah untuk dijual dan diperjualbelikan dalam rangka mendapatkan laba. ${ }^{3}$ Al-Gazali bersikap sangat kritis terhadap laba yang berlebihan. Menurutnya, jika seorang pembeli menawarkan harga "yang lebih tinggi" dari pada "harga yang berlaku", penjual harus menolaknya, karena laba akan menjadi berlebihan. ${ }^{4}$

\footnotetext{
${ }^{1}$ Zainol Hasan, Mahyudi, Analisis terhadap Pemikiran Ekonomi Kapitalisme Adam Smith. Istidlal: Jurnal Ekonomi dan Hukum Islam, Vol. 4, No. 1, 2020, Hal. 24-25

${ }^{2}$ Agustiati, Sistem Ekonomi Kapitalisme, Academica, Vol. 1, No. 2, 2008, Hal. 154

${ }^{3}$ Zainol Hasan, Mahyudi, Analisis terhadap Pemikiran Ekonomi Kapitalisme Adam Smith. Istidlal: Jurnal Ekonomi dan Hukum Islam, Vol. 4, No. 1, 2020, Hal. 26

${ }^{4}$ Sirajuddin, Konsep Pemikiran Ekonomi Al-Ghazali. Laa Maisyir: Jurnal Ekonomi Islam, Vol. 3, No. 1, Thn. 2016, Hal. 54
} 
3. Karl Marx mendifinisikan kapitalisme sebagai corak atau introduksi golongan kapitalis. Adapun corak yang kaum kapitalis sadari adalah dimotivasi oleh pemikiran pola ekonomi dalam rangka menumpuk kekayaan.

4. Ayn Rand mendefinisikan kapitalisme laksana suatu sistem sosial yang berlandaskan pada pengakuan atas hakhak personal, termasuk hak milik dimana semua kepemilikan adalah eksklusif. $^{5}$

\section{Pilar-pilar sistem ekonomi}

kapitalis Sistem ekonomi kapitalis ini menyadarkan diri secara penuh kepada hal-hal di bawah ini:

a. Private property atau hak milik swasta.

b. The invisibel hand atau dibina oleh tangan tak terlihat.

c. Idividualisme ekonomi.

d. Free market kompetition atau persaingan dan pasar bebas. ${ }^{6}$

Dalam teori ekonomi kapitralis mekanisme pasar didasarkan pada prinsip pasar bebas dengan pengawasan atau free market with supervision. Artinya, pemerintah hanya mengawasi saja tidak boleh ikut campur. Pemerintah hanya sebagai penonton. ${ }^{7}$

Smith mengajukan sebuah teori harga yang ia sebut sebagai teori harga alamiah. Harga alamiah adalah harga pasar dalam kerangka equilibrium (keseimbangan) yang panjang sebagai hasil kekuatan-kekuatan alamiah dalam suatu masyarakat.

Adam Smith dalam Wealth of Nations menjelaskan teori nilai berdasarkan nilai dari suatu pekerjaan, dan terutama sekali tenaga kerja, menurut Adam Smith tenaga kerja adalah merupakan sebab dan sekaligus alat pengukur nilai.

Smith mengambil kesimpulan bahwa produktivitas tenaga kerja dapat ditingkatkan melalui apa yang disebutnya dengan pembagian kerja (division of labour).

\footnotetext{
${ }^{5}$ Zainol Hasan, Mahyudi, Analisis terhadap Pemikiran Ekonomi Kapitalisme Adam Smith. Istidlal: Jurnal Ekonomi dan Hukum Islam, Vol. 4, No. 1, 2020, Hal. 26

${ }^{6}$ Muhammad Tho'in, Konsep Ekonomi Islam Jalan Tengah (Kapitalis-Sosialis). Jurnal Ilmiah Ekonomi Islam, Vol. 1, No. 03, 2015, Hal. 120

${ }^{7}$ Moch. Bukhori Muslim, Perbandingan ekonomi Islam dan ekonomi kapitalis. Al-Iqtishad: Jurnal Ilmu Ekonomi Syariah, Vol. 4, No. 2, 2012, Hal. 313
} 
Pembagian kerja akan mendorong spesialisasi, di mana orang akan memilih mengerjakan yang terbaik sesuai dengan bakat dan kemampuannya masing-masing. ${ }^{8}$

\section{DAFTAR PUSTAKA}

Agustiati, A. (2009). Sistem Ekonomi Kapitalisme. Academica, 1(2).

Hasan, Z., \& Mahyudi, M. (2020). Analisis terhadap Pemikiran Ekonomi Kapitalisme Adam Smith. Istidlal: Jurnal Ekonomi dan Hukum Islam, 4(1), 24-34.

Hidayatullah, I. (2018). Pandangan Ibnu Khaldun dan Adam Smith Tentang Mekanisme Pasar. IQTISHODUNA: Jurnal Ekonomi Islam, 7(1), 117-145.

Muslim, M. B. (2012). Perbandingan ekonomi Islam dan ekonomi kapitalis. Al-Iqtishad: Jurnal Ilmu Ekonomi Syariah, 4(2).

Sirajuddin, S. (2016). Konsep Pemikiran Ekonomi Al-Ghazali. Laa Maisyir: Jurnal Ekonomi Islam, 3(1).

Tho'in, M. (2015). Konsep Ekonomi Islam Jalan Tengah (Kapitalis-Sosialis). Jurnal Ilmiah Ekonomi Islam, 1(03).

8 Indra Hidayatullah, Pandangan Ibnu Khaldun dan Adam Smith Tentang Mekanisme Pasar. IQTISHODUNA: Jurnal Ekonomi Islam, Vol. 7, No. 1, 2018, Hal. 129-130 